Impact and control of protozoan parasites in maricultured fishes

Buchmann, Kurt

Published in:

Parasitology

DOI:

10.1017/S003118201300005X

Publication date:

2015

Document version

Early version, also known as pre-print

Citation for published version (APA):

Buchmann, K. (2015). Impact and control of protozoan parasites in maricultured fishes. Parasitology, 142(special issue 01), 168-177. https://doi.org/10.1017/S003118201300005X 


\title{
Impact and control of protozoan parasites in maricultured fishes
}

\author{
KURT BUCHMANN* \\ Laboratory of Aquatic Pathobiology, Section of Biomedicine, Department of Veterinary Disease Biology, Faculty of Health \\ and Medical Sciences, University of Copenhagen, Denmark
}

(Received 14 November 2012; revised 8 Fanuary 2013; accepted 8 Fanuary 2013; first published online 1 March 2013)

SUMMARY

Aquaculture, including both freshwater and marine production, has on a world scale exhibited one of the highest growth rates within animal protein production during recent decades and is expected to expand further at the same rate within the next 10 years. Control of diseases is one of the most prominent challenges if this production goal is to be reached. Apart from viral, bacterial, fungal and metazoan infections it has been documented that protozoan parasites affect health and welfare and thereby production of fish in marine aquaculture. Representatives within the main protozoan groups such as amoebae, dinoflagellates, kinetoplastid flagellates, diplomonadid flagellates, apicomplexans, microsporidians and ciliates have been shown to cause severe morbidity and mortality among farmed fish. Well studied examples are Neoparamoeba perurans, Amyloodinium ocellatum, Spironucleus salmonicida, Ichthyobodo necator, Cryptobia salmositica, Loma salmonae, Cryptocaryon irritans, Miamiensis avidus and Trichodina jadranica. The present report provides details on the parasites' biology and impact on productivity and evaluates tools for diagnosis, control and management. Special emphasis is placed on antiprotozoan immune responses in fish and a strategy for development of vaccines is presented.

Key words: fish, parasites, protozoans, health, productivity, impact, vaccine, control.

\section{INTRODUCTION}

Production of teleosts in the marine environment is a rapidly developing aquacultural activity worldwide. In relation to the known number of fish species described, which counts more than 28000 species (Nelson, 2006), relatively few of these $(<400$ species $)$ are currently being propagated under artificial conditions. However, even on this constricted basis, production of marine fish in aquaculture enterprises is a prominent player on the world market. In 2010, the Atlantic salmon (Salmo salar) was produced in quantities of more than 1.5 million tonnes, milkfish (Chanos chanos) production exceeded 0.8 million tonnes and sea bass (Dicentrarchus labrax) and sea bream (Sparus aurata) rearing reached more than 450000 tonnes (FAO, 2012). As in all other types of husbandry, infectious diseases represent one of the main obstacles for safe production securing a high level of animal welfare (Rodgers and Furones, 1998; Segner et al. 2012). Viral, bacterial and fungal diseases represent well known challenges to mariculture enterprises and call for special methods for successful control. Strategies rely on improved management procedures, breeding of resistant fish,

* Corresponding author: Laboratory of Aquatic Pathobiology, Section of Biomedicine, Department of Veterinary Disease Biology, Faculty of Health and Medical Sciences, University of Copenhagen, Stigbøjlen 7, DK-1870 Frederiksberg C., Denmark. Tel: +4535332700. Fax: +45-35332755. E-mail:kub@sund.ku.dk chemical/medical intervention and immunoprophylaxis including vaccination, which is currently used for control of bacterial diseases. Metazoan parasites including helminths and crustaceans are also considered severe pests in mariculture enterprises and these parasites are in many cases visible to the naked eye and therefore easily diagnosed disease agents. Protozoans are limited in size and more difficult to diagnose. If infections are observed macroscopically this will be due to pathological tissue changes (hyperplasia, hypertrophy or necrosis of host tissue) induced by the protozoans. Despite the limited size of protozoans their pathogenic effects on fish may be devastating and can negatively impact on fish production. The present report provides examples of problems in marine fish farming caused by amoebae, flagellates, apicomplexans, microsporideans and ciliates.

\section{AMOEBAE}

\section{Neoparamoeba perurans}

Salmon farming in Tasmania, Europe, South America and North America suffers from infections with amoebae of the species Neoparamoeba perurans, a parasite causing amoebic gill disease (AGD) in Atlantic salmon ( $S$. salar) in marine fish farms (Young et al. 2007; Rozas et al. 2012). It is one of the best documented gill diseases in salmon farming eliciting high morbidity and some mortality. Other 
species of Neoparamoeba have been isolated from various marine fishes (Dyková et al. 2007) but only $N$. perurans has been proven explicitly to elicit pathological reactions in fish gills (Young et al. 2008). Apart from Atlantic salmon host fishes such as coho salmon (Oncorhynchus kisutch), chinook salmon (O. tshawytscha), rainbow trout (O. mykiss), ayu (Plecoglossus altivelis), sea bass (D. labrax) and turbot (Scophthalmus maximus) have been diagnosed with AGD (Nowak, 2012). Amoebae induce hyperplasia in affected gill areas where inflammatory foci, clubbing and filament fusion may occur. Diagnosis requires use of molecular tools (PCR or in situ hybridization) because light microscopy cannot differentiate between e.g. genera Paramoeba and Neoparamoeba, both carrying eukaryotic endosymbionts. Neoparamoeba perurans is a marine species and treatment can be performed by freshwater bathing but use of hydrogen peroxide treatments have shown some effects as well (Nowak, 2012). Irritation of gill epithelia following invasion by amoebae lead to IL-1beta expression followed by hyperplasia (Adams and Nowak, 2003) and higher infections lead to extensive inflammatory responses with infiltration of reactive cells. These reactions clearly indicate that host immune responses are activated following infection but also that they are part of the pathological reactions destroying the architecture of the gill tissue leading to decreased oxygen uptake and carbon dioxide release (Nowak, 2012). Control strategies may include breeding for resistant salmon strains but immunoprophylactic measures should be considered as well. Feeding salmon with immunostimulating feed additives, which often has been suggested to boost the fish immune system, did not show a satisfactory effect on infection levels (Bridle et al. 2005). Vaccines (immersion or injection) based on live or killed amoebae and even DNA vaccines have been tested experimentally but without showing any significant efficacy (Nowak, 2012).

\section{DINOFLAGELLATES}

Amyloodinium ocellatum

The dinoflagellate $A$. ocellatum has an ectoparasitic life style and has been considered a pest in marine aquaculture for decades due to its association with severe morbidity and mortality (Paperna, 1981; Pereira et al. 2011; Saraiva et al. 2011; Soares et al. 2012). The sessile stage on fish is termed the trophont, attaching itself by rhizoids penetrating surface epithelia of gills, skin and fins of host fishes. Multiplication occurs in the environment in a cyst stage termed the tomont. Numerous infective dinospores are released from the cyst whereafter the fish can acquire additional infections (Noga, 1987). The characteristic parasite is easily diagnosed by light microscopy but molecular diagnostic tools including
PCR and sequencing of rDNA have been developed (Levy et al. 2007). The pathogenic effect of the parasite is associated with severe disturbance of epithelia which evidently can lead to osmoregulatory problems in the host fish (Noga, 1987). Effective treatment of infections has been achieved by use of auxiliary compounds containing formalin, copper and hydrogen peroxide, but experimental trials have shown that also drugs such as chloroquine chloride and a series of antibiotics have effects on $A$. ocellatum infections in fish (Noga, 2012). Epithelial sloughing and rhizoid penetration will presumably activate a series of immune reactions which have not been fully described but the severe hyperplasia and inflammatory reactions elicited by the parasites are probably associated with extensive production of cytokines. A series of antimicrobial peptides such as HLPs (histone-like proteins) and piscidins produced in the skin of certain fish species show a clear killing effect on dinospores. It has also been shown that specific serum antibodies occur in hosts following infection and recovery (Smith et al. 1992; Cecchini et al. 2001) which at least could partly explain the dinospore-agglutinating activity of tilapia serum (Smith et al. 1993). Clown fish (Amphiprion frenatus) surviving from experimental infections developed acquired immunity to reinfection lasting for half a year (Cobb et al. 1998) which suggest that development of a protective vaccine may be a realistic future goal.

\section{Ichthyodinium $s p p$.}

The endoparasitic dinoflagellate Ichthyodinium was previously known from wild fish and fish eggs but following the advent of cod (Gadus morhua) farming (Buchmann et al. 1993; Pedersen et al. 1993) fish and eggs from these marine species were found to be infected by dinoflagellates during routine investigations for diseases and a tentative diagnosis based on light microscopy was made. However, a precise generic diagnosis was only recently obtained following sequencing of rDNA from the organism (Skovgaard et al. 2010). The parasite occurs as a trophozoite in eggs and yolk sac larvae and it was initially suggested that infection could affect host survival, a suggestion, however, that could not be confirmed by Skovgaard et al. (2010). The absence of multiplication in eggs and larvae of cod indicated that the stimulation of immune factors is minimal and thereby pathological reactions are absent. However, Mori et al. (2007) reported severe health and quality problems associated with multiplication of Ichthyodinium parasites in eggs and larvae of leopard coral grouper (Plectropomus leopardus). Control efforts using chemical or medical treatment may be difficult due to the endoparasitic nature of this parasite and the fragility and vulnerability of eggs and yolk sac larvae. Therefore it is advisable to introduce improved prophylactic hygienic measures combined with use 
of certified disease-free spawners, eggs and larvae in order to eliminate infections. An alternative, but still theoretical, immunoprophylactic strategy may be immunization of spawners with subsequent transfer of protective immune elements in the egg.

\section{KINETOPLASTID FLAGELLATES}

\section{Cryptobia salmositica}

The kinetoplastid flagellate $C$. salmositica infects Pacific salmon belonging to the genus Oncorhynchus and may cause considerable mortality in marine net pens. It has relatively low host specificity and may also infect sculpins (Cottus spp.) and Salvelinus fontinalis (Woo, 2012). Although leeches (Piscicola salmositica) are known to transmit these flagellates a direct transfer from host to host under high host densities has been described. The parasite penetrates the fish surface and may remain in this microhabitat, but the main pathogenic effect is associated with extensive parasitaemia. The parasite's production of cysteine- and metallo-proteases is considered to provide the parasite with penetration tools and to be responsible for anaemia (Woo, 1979). Inflammatory reactions lead to oedema, ascites and exophthalmia with a general decrease in physiological functions associated with lethargy and anorexia. The drug isometamidium chloride (Samorin), which is a known anti-trypanosomal compound, also exerts action against crytobiosis in certain stages but not the acute phase of the disease (Ardelli and Woo, 1999). The occurrence of the flagellate in the host vascular system evidently stimulates both innate and adaptive immune responses. High antibody titres have been measured in fish surviving an infection. The alternative complement activation pathway may confer protection to naturally resistant fish. Several strategies for development of vaccines against cryptobiosis have been tested including vaccination with cultured attenuated parasites (Woo and Li, 1990), recombinant protein vaccines and DNA-vaccines (Tan et al. 2008).

\section{Ichthyobodo necator}

This flagellate (Fig. 1) is found both in freshwater and marine facilities. There is debate whether more than one species is involved and recent studies have provided molecular clues to differentiation of different strains and species within the genus Ichthyobodo (Isaksen et al. 2012). The parasite infects both skin and gill epithelia and is associated with considerable morbidity and even mortalities (Urawa et al. 1998). The parasite occurs in two forms, a motile and a sessile stage. The latter is probably the most pathogenic due to its attachment and penetration of host epithelia. Both stages are susceptible to auxiliary chemical compounds such as formalin and various oxidizing agents (hydrogen peroxide, sodium percarbonate, peracetic acid). The latter group will, from

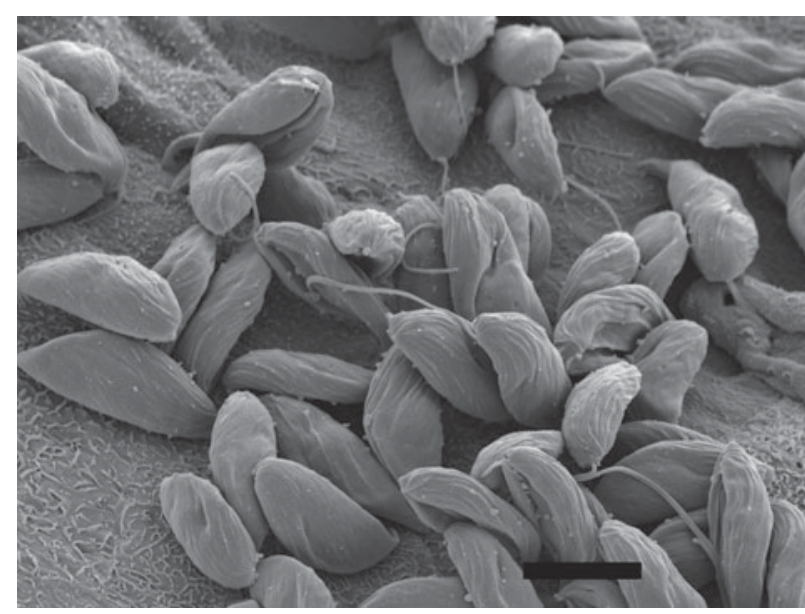

Fig. 1. Ichthyobodo necator on dorsal fin of rainbow trout. Scale bar $5 \mu$ M. Courtesy of Dr. O. S. Møller, Zoological Museum, University of Copenhagen, Denmark.

an environmental perspective, be needed in future production facilities should they be based on principles of sustainability. Host reactions include mucous cell involvement and hyperplasia (Urawa, 1992; Urawa et al. 1998) and recent studies have shown that experimental infections induce $\mathrm{T}$ cell and $\operatorname{Ig} \mathrm{T}$ lymphocyte depletion in skin whereas IgM-positive lymphocytes accumulate in the infected epidermis (Chettri et al.2012). Cytokine profiling indicated that the parasites initiate a $\mathrm{T}_{\mathrm{H} 2}$-like response in rainbow trout skin being based on up-regulation of IL-4/13 and IL-10 genes. Furthermore, increased occurrence of IgM-producing lymphocytes in the skin supports this notion. Given the recent information that rainbow trout utilize IgT responses combined with $\mathrm{T}$ cell involvement in gills when mounting effective responses against white spot disease (Jørgensen et al. 2011; Olsen et al. 2011) it may be worth reflecting on the possibility that manipulation of host responses towards $I$. necator in a similar way could increase protection from a low to an acceptable level.

\section{DIPLOMONADID FLAGELLATES}

Spironucleus salmonis was originally described as Hexamita salmonis; it is a common intestinal parasite in farmed rainbow trout (Buchmann et al. 1995) eliciting intestinal dysfunction and weight loss probably due to malabsorption (Uldal and Buchmann, 1996). Reports on extraintestinal occurrence of a diplomonadid, previously diagnosed as $H$. salmonis (Kent et al. 1992; Poppe et al. 1992) in maricultured salmonids framed the pathological importance of diplomonadids. It was later suggested that the causative agent was a corresponding species Spironucleus barkhanus previously recorded in grayling (Thymallus thymallus) and arctic charr (Salvelinus alpinus) (Sterud et al. 1998) which was suspected in the spread of the infection to Atlantic salmon and in the subsequent appearance of extra-intestinal 
abcesses. However, molecular studies showed that the pathogen was a closely related but new species, Spironucleus salmonicida (Jørgensen and Sterud, 2006). The parasite's pathogenicity is associated with penetration of various tissues including muscles and it has obviously an ability to evade innate responses of salmon. Treatment of spironucleosis was previously conducted by the use of nitro-imidazoles such as metronidazole, but due to the ban of this drug in husbandry, including fish farming, alternative compounds have been tested for possible antiparasitic effects. Garlic extracts were indeed found to affect the related flagellate Spironucleus vortens (Millet et al. 2011) which suggests that alternative drugs should be tested also for S. salmonicida. Possible immunoprophylactic measures including immunostimulants and/or vaccination should be investigated. This area has many research opportunities due to the fact that the nature of the host immune response towards these diplomonadid flagellates has not yet been established.

\section{APICOMPLEXA}

A number of apicomplexan species are common in wild fish from both freshwater and marine habitats. However, reports on apicomplexan infections in maricultured fish are few. When Heuch et al. (2011) compared parasite infections in wild and maricultured $\operatorname{cod}(G$. morhua) in Norway they detected Goussia spraguei as the only species within this group and occurring only in wild fish. However, turbot (S. maximus) farms in North West Spain were diagnosed with Cryptosporidium scophthalmi (AlvarezPellitero et al. 2004). Although no evidence for severe impact of infection was recorded, the authors showed histopathological changes of the host intestinal epithelium with leukocyte infiltration. Tissue changes associated with Cryptosporidium spp. infections mainly of juvenile farmed turbot were reported from Portugal (Saraiva et al. 2009) where the parasite was found in bile duct epithelial cells. No experimental treatments of these infections were performed but it may be worthwhile testing if anticoccidian compounds such as toltrazuril may have a curative effect (Schmahl et al. 1989). The trend for a lower prevalence and intensity with older fish suggest development of age-dependent immunity against these apicomplexans corresponding to anti-coccidian responses in birds and mammals. This suggests that further investigations on immune reactions in marine piscine hosts should be performed in order to elucidate immune mechanisms and potentials for immunoprophylactic strategies.

\section{MICROSPORID IA}

A range of microsporidians has been detected in various maricultured fishes. One of these is Loma salmonae in salmonids (Speare and Lovy, 2012), but also Pleistophora anguillarum in Japanese eels (Anguilla japonica) (Hung et al. 1996) and Enterocytozoon spp. in Atlantic halibut (Hippoglossus hippoglossus) (Bergh et al. 2001) have been associated with pathological reactions in farmed fishes.

\section{Loma salmonae}

Pacific salmon cultured in marine net-pens are particularly affected by $L$. salmonae which primarily infects gill tissue but may be found in other organs (e.g. intestine) as well. Parasite spores develop in a host cell producing relatively large whitish xenomas which rupture within weeks whereupon spores are released to the environment. Implementation of hygienic procedures including fallowing of production sites for extended time periods may be an important prophylactic strategy. Partial treatment success against the parasitosis using fumagillin, albendazole or monensin has been reported (Speare and Lovy, 2012). The inflammatory response to xenoma development is absent or minimal and restricted to a weak fibroblast migration towards the infected cell surface (Speare and Lovy, 2012). This may indicate that the parasite in this stage has an immune modulating mechanism securing fulfilment of the life cycle. However, following rupture and release of spores a marked inflammatory response develops possibly due to stimulation of damaged and exposed gill tissue by external biotic and abiotic factors. The immune response following spore release is initially based on neutrophil colonization followed by macrophage and lymphocyte attraction. Even dendritic-like cells may take part in the host response (Lovy et al. 2006). Humoral host responses against microsporidian parasites are known to occur. Japanese eel (Anguilla japonica) is able to mount an antibody reaction against a series of antigens in $P$. anguillarum (Buchmann et al. 1992; Hung et al. 1996) and the combined cellular and humoral reactions may be decisive elements when developing future immunoprophylactic strategies. Feeding of hosts with immunostimulants such as beta-glucans has been described to diminish the infection severity (Guselle et al. 2010) but more effective methods should be considered. Fish surviving an infection achieve protection against reinfection which indicates that vaccine development may be a realistic goal. Experimental vaccines have indeed been found to protect rainbow trout (Sánchez et al. 2001).

\section{I L I A T ES}

A suite of ciliates has been associated with disease and mortality in mariculture. Marine white spot disease caused by Cryptocaryon has been in focus due to its common occurrence in exhibition aquaria and traditional warm water fish farming. During the last 


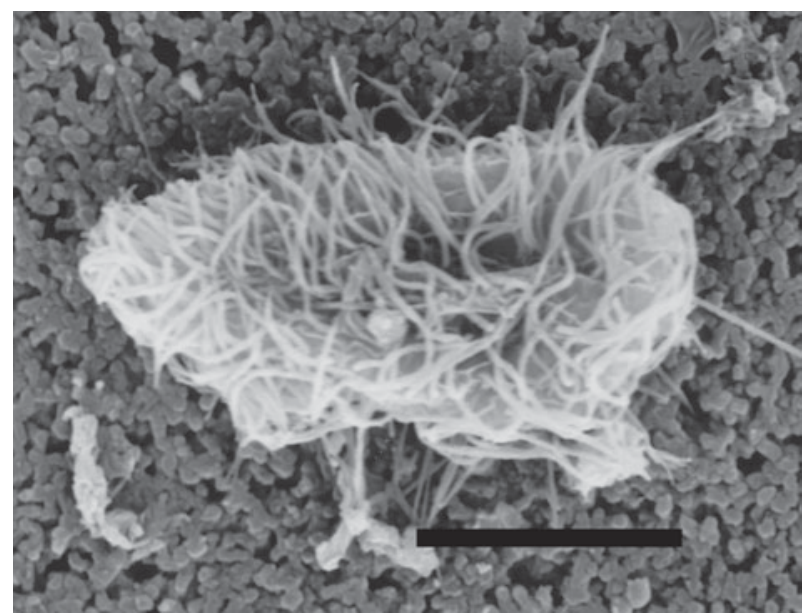

Fig. 2. Invasive scuticociliate isolated from brain of turbot. Scale bar $10 \mu \mathrm{m}$. Courtesy of Dr J. Bresciani, University of Copenhagen, Denmark.

two decades also scuticociliates have been shown to be aggressive invaders of host fish tissues whereas trichodinids only occasionally cause severe problems.

\section{Cryptocaryon irritans}

Cryptocaryon irritans is an endoparasite penetrating the host epidermis, feeding on sloughed cells inducing a marked proliferation of epidermal cells whereby the parasite location become macroscopically visible as white spots (Yambot et al. 2003). This parasitic ciliate has a resemblance to the freshwater parasite Ichthyophthirius multifiliis and has a corresponding but marine life cycle. However, analyses of rDNA sequences suggest that the two ciliates are merely distantly related and the biological similarities may be due to convergent evolution (Colorni and Diamant, 1993). As is known from its freshwater counterpart $C$. irritans also induces specific antibody production in infected fish host (Misumi et al. 2011) which suggests that immunoprophylactic measures including vaccination may be a future way of controlling the disease. Treatments using various drugs and chemicals (of which some are environmentally friendly) have been and will probably in the near future be essential ways of reducing infection levels in farms (Picón-Camacho et al. 2011).

\section{Scuticociliates}

Farmed flatfishes, such as turbot ( $S$. maximus) and olive flounder (Paralichthys olivaceus) and percids, such as sea bass (D. labrax), have been found invaded by aggressive and invasive minute ciliates (Fig. 2). Specific diagnosis of these pathogens is often hampered due to a high degree of morphological similarity between these ciliates. Recent work has synonymized two species, Miamiensis avidus and Philasterides dicentrarchi, which have been repeatedly reported to be disease agents. This was partly based on recent developments within molecular biology which have improved diagnostic techniques. The small subunit ribosomal RNA gene (SSU rRNA) has proven useful for differentiation of genera, species and strains (Song et al. 2009). As a consequence, a number of other valid species within the genera Uronema and Pseudocohnilembus have been reported as pathogens in fish. Miamiensis avidus is a histophagous parasite invading skin, gills, muscles, brain, spinal cord and gut. The parasites are facultatively parasitic and may survive and propagate in the environment which may be problematic when control measures have been implemented. Implementation of hygienic measures is the first step to prevent infection. Auxiliary substances, including formalin and hydrogen peroxide-containing compounds, are known to kill free-living stages but tissue-dwelling stages need medication that interferes with essential physiological pathways of the parasite (Iglesias et al. 2002). Feeding fish with immunostimulants can induce a general immune response which may have a controlling effect on scuticociliate infections. Among several reports Lee and Kim (2009) also showed that oligonucleotides (CpG$\mathrm{ODN}$ ) induced resistance in olive flounder against M. avidus. The infected fish raise antibody responses against the ciliates and several attempts to produce a protective vaccine have been made. Recently high protection combined with few side-effects was recorded in turbot following immunization with surface antigens of $M$. avidus mixed with polymeric microspheres (León-Rodríguez et al. 2012). Although high hygienic standards and chemotherapy may be convenient control measures immunoprophylactic methods may also have a future as can be deduced from these recent vaccine studies.

\section{Trichodina jadranica}

Trichodinids (Fig. 3) are prevalent parasites both in freshwater and marine fish culture systems. Numerous species occur in most geographic regions and climatic zones from arctic cod culture (Heuch et al. 2011) to tropical bass (Lates calcarifer) production (Rückert et al. 2008). A well-studied species is $T$. jadranica which is an ectoparasite with limited pathological effects on the host if the infection level is limited. However, it has the potential to harm its host severely when the parasite load reaches high levels. European eels (Anguilla anguilla) farming in recirculated water, both fresh and marine, have suffered from recurrent attacks by T. jadranica (Madsen et al. $2000 a$ ). The ciliates attach to skin, fins and gills of the European eel but do not penetrate the epidermis. With its basic disc, reinforced by a rigid cytoskeleton with contractile elements, the parasite can attach firmly to the host surface and compress the epithelial cell lining, whereby normal physiological functions 


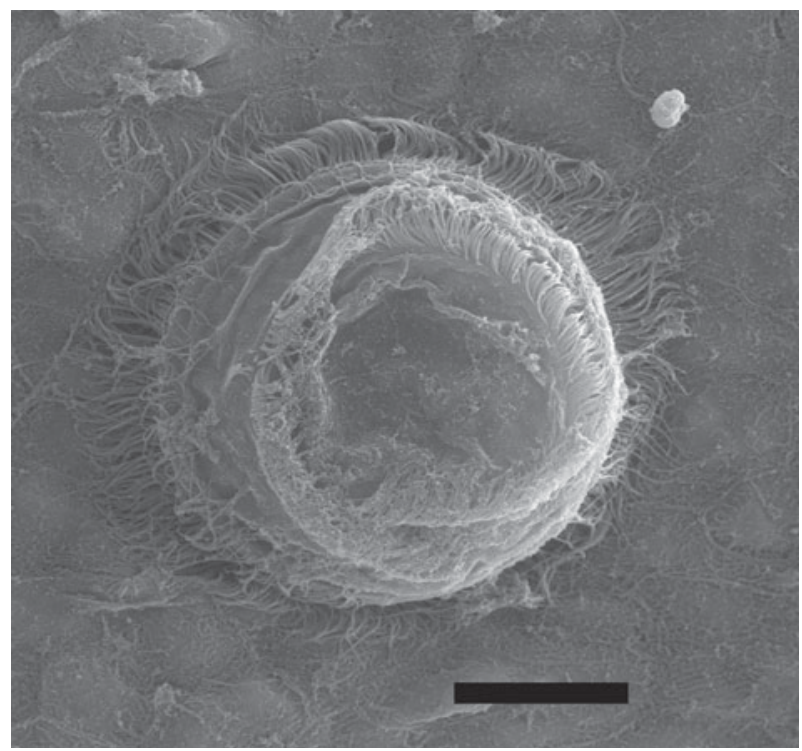

Fig. 3. Trichodina sp. on caudal fin of rainbow trout. Scale bar $20 \mu \mathrm{m}$. Courtesy of Dr J. Bresciani, University of Copenhagen, Denmark.

(e.g. gas exchange, ammonia release) are inhibited. Lethargy, anorexia and death may result from heavy infections. Although weaker individuals in the host population seem to be the most susceptible no reports on acquired immunity are available. The ciliates feed on bacteria and organic particles which explains excessive parasite propagation in polluted water. Thus, it is known that mass occurrence of the parasite is connected to a high organic content of the fish farm water (Madsen et al. 2000b). Reducing the organic load of fish farm water by mechanical filtration is therefore a relevant management tool for prevention of infections but in acute cases auxiliary chemical compounds such as formalin have been used to reduce infection levels. Due to the environmental and health hazards connected with the use of formalin alternative compounds are recommended for control. Oxidizers including hydrogen peroxide-containing products and even garlic juice were found to be effective for elimination of these parasites (Madsen et al. 2000a).

\section{DISCUSSION}

\section{Future diagnostic methods}

Early classical descriptions of protozoans have relied on line drawings and light microscopy photographs with written reports on morphometric observations. Later, scanning and transmission electron microscopy improved the diagnostic precision (Lom and Dyková, 1992) and during recent decades sequencing of selected gene regions such as rDNA and mitochondrial DNA have improved resolution even further. It is to be expected that development of sequencing techniques will allow us to obtain information of a much larger part of the genome of protozoan parasites and thereby create highly precise diagnoses. Although morphometric and molecular information is basic and indispensable for the diagnosis it should also be considered to include in vitro or in vivo infection experiments in certain problematic cases. Even small and not easily detectable mutations in a pathogen can produce very large differences in infectivity with regard to a certain host organism. Thus, a single transition in the ITS region of the helminth Gyrodactylus salaris (Jørgensen et al. 2007) is associated with profound differences in infectivity for Atlantic salmon. Likewise, a few substitutions in the genome of the bacterium Yersinia ruckeri have created a pathogen with different antigenic properties leaving old vaccines ineffective (Desmukh et al. 2012).

\section{Future disease control}

Chemical control. Many diseases in fish are caused by ectoparasitic protozoans invading skin, fins and gills. These organisms apply free-living life cycle stages (cysts, swarmers) which makes it possible to control the infections through water disinfection by use of substances such as copper sulphate and formalin. Due to the environmentally problematic effects of these compounds recent studies have recommended alternative uses of oxidizers such as hydrogen peroxide and related compounds (sodium percarbonate, peracetic acid).

Medical control. Several drugs with antiprotozoan effects have been developed and are available for treatment of humans and domestic animals. However, although experimental work has demonstrated marked activity against fish protozoans, their use within aquacultural enterprises is limited due to lack of licensing and to legislative restrictions. Nitroimidazoles such as metronidazole and dimetridazole show a strong effect on flagellates and ciliates and this drug group is allowed for human use but not for food production animals. Likewise, the anticoccidian drug toltrazuril can be used for prevention of ciliate infections in fish (Jaafar and Buchmann, 2011). It is licensed for use in the poultry and pig industry but it is questionable if the drug can be licensed for aquacultural animals as well.

Management. Strict hygienic measures, quarantine practices, compulsory use of certified disease-free fish, fallowing of production sites and elimination of infective parasite stages by various filtration techniques are practices which should be used in any production system. Thus, water filtration by the use of mechanical filters may (dependent on the mesh size) remove potentially harmful tomonts of 
C. irritans and thereby prevent multiplication within tomocysts.

Breeding of innately resistant fish. Mechanisms involved in and responsible for innate resistance of specified stocks and species of fish towards pathogens have not been fully elucidated. However, a range of examples is available. A well-documented example is the innate resistance of several Baltic salmon strains against the ectoparasitic monogenean G. salaris (Bakke et al. 1990; Dalgaard et al. 2003; Lindenstrøm et al. 2006). In addition, susceptibility and resistance of various salmonids towards the bacterial pathogen Aeromonas salmonicida was also reported to vary significantly between salmon strains (Holten-Andersen et al. 2012). It is therefore relevant to initiate breeding programmes in order to develop strains with a low susceptibility towards pathogens including protozoans.

Immunoprophylaxis. The potential and capacity of the teleost immune system can be appreciated through recent discoveries which have suggested that immunoprophylactic measures may be significant ways to secure fish health. Some strategies in the field are based on feeding of fish with compounds often termed immunostimulants which are chemicals stimulating innate immune parameters. Other strategies apply specific immunization of their production animals against pathogens.

Immunostimulants. A series of structural molecules from various sources e.g. bacteria, yeast, fungi and lichens alone or together with synthetic products (e.g. oligonucleotides) is currently used as immunostimulants. A large group of compounds on this product shelf is the beta-glucans (Skov et al. 2012). The immunostimulants possess pathogenassociated molecular patterns (PAMPS) which are able to stimulate different pathogen recognition receptors (PRRs) in host fishes and thereby activate innate immune reactions (Chettri et al. 2011). These comprise among others toll-like receptors which subsequently can initiate cascade reactions which may limit or reduce infections. Results from controlled laboratory (Jaafar et al. 2011) or field studies (Xueqin et al. 2012) have indicated that immune elements are activated by these feed additives. Unfortunately the effect of these feed additives on parasite infection levels, such as intensities of the skin parasitizing ciliate $I$. multifiliis, is limited. Correspondingly, immunostimulant feeding does not result in a clear reduction of $L$. salmonae infection in salmonids but merely leads to a more benign course of infection (Guselle et al. 2010). Likewise, AGD in salmon is not diminished by in-feed immunostimulants (Bridle et al. 2005). Therefore other immunoprophylactic strategies are needed in order to secure a satisfactory fish health level.
Vaccination. Disease control in aquacultural enterprises must ideally be based on integrated systems applying high hygienic standards. This can be achieved through filtration of water (with mechanical and biological filters) securing optimal physicochemical water parameters, by breeding for resistant fish strains and feeding at an optimal level. However, additional control methods must be considered in order to avoid medication. Vaccination is an immuno-prophylactic measure which can provide the fish with a high resistance against infection. Significant results with development of antibacterial vaccines have been achieved in the Norwegian salmon industry where the use of antibiotics has been reduced by $99 \%$ during the latest 26 years despite a 20 -fold increase of the annual salmon production. High efficacies of anti-viral vaccines have also been demonstrated (Lorenzen et al. 2000) and efforts should therefore be made in order to develop antiparasitic vaccines. Due to the limited size of many protozoan parasites the cellular and humoral immunological armament in fish should have the basic ability to develop protective immunity against at least some of these pathogens. Experimental vaccines against C.salmositica (Woo, 2012), L. salmonae (Sánchez et al. 2001; Rodríguez-Tovar et al. 2006) and I. multifiliis (the freshwater equivalent to C.irritans) (Alishahi and Buchmann, 2006) have been found to be partially effective which is promising for further achievements. Cryptocaryon irritans is known to elicit antibody production in affected fish (Misumi et al. 2011) which is a valuable basis for further vaccine development. Experimental studies have also demonstrated significant activation of cellular and humoral immune factors in fish exposed to several other protozoans such as $A$. ocellatum (Noga, 2012) and I. necator (Chettri et al. 2012). Thus, it is likely that production of vaccines against $A$. ocellatum, S. salmonicida, I. necator and L. salmonae may be realistic goals for renewed research efforts. However, it cannot be excluded that the parasites themselves or parasitederived molecules (Jørgensen and Buchmann, 2011) divert the response of the host towards a less effective immune pathway and this possibility should be taken into account when designing vaccines and their adjuvants. The recent development of reagents and tools for investigating immune mechanisms in fish can create a basis for tailor-made vaccines stimulating immune mechanisms in fish hosts which can provide protection.

CONCLUSIONS AND FUTURE DIRECTIONS

Control of protozoan infections of maricultured fishes must be performed through integrated efforts applying prophylactic management methods creating a better physical environment for the captive fishes. Breeding for natural resistance and improved nutrition should also be a priority area which can add to a 
high health status in mariculture enterprises. Application of chemicals and drugs may be necessary tools during acute outbreaks but more sustainable methods should be implemented to avoid infections. It should be noted that vaccine development is a central task to be performed in order to exploit the high potential of the fish immune system and reach sustainability in fish farming. At present, most experimental approaches can be considered rather primitive and coarse vaccines based on crude parasite preparations may not be sufficient for obtaining protection and reaching production goals and high welfare of farmed fish. Basic research on immune mechanisms responsible for protection of fish against protozoan diseases can direct future production of tailor-made vaccines for specific parasitic diseases (Jørgensen and Buchmann, 2011). The immunological network in fish is extensive and different parasites may lead the immune reactions in directions which are not optimal for protection. It has been shown that the development of reagents and their use in a range of assays such as immunohistochemistry, immunocytochemistry, flow-cytometry, gene expression technology combined with in vivo challenge studies can improve our understanding of fish immune reactions, their diversity and potential. Due to limited cross-reactivity of reagents developed for salmonids (e.g. rabbit antibodies reacting with fish IgM) with regard to cyprinids, anguillids, percids, gadids and pleuronectids (Buchmann and Pedersen, 1994) it is necessary to initiate these research initiatives for all the main fish taxa. Specific reagents for the major fish groups in aquaculture should be developed in order to provide a basis for elucidation of fish immune responses against protozoans in mariculture. Priorities should be reagents to describe innate, adaptive responses, cellular (macrophage, $\mathrm{T}$ cell and B cell markers) and humoral elements (various immunoglobulin classes, complement factors, acute phase reactants, cytokines) within these reaction pathways. This basic knowledge may eventually lead to optimization of vaccines not only for fish in mariculture but also for higher vertebrates.

\section{ACKNOWLEDGEMENTS}

This work was produced under the Danish Fish Immunology Research Centre and Network DAFINET (www.dafinet.dk) supported by the Danish Council for Strategic Research.

\section{REFERENCES}

Adams, M. B. and Nowak, B. F. (2003). Amoebic gill disease (AGD): sequential pathology in cultured Atlantic salmon (Salmo salar L.). Fournal of Fish Diseases 26, 601-614

Alishahi, M. and Buchmann, K. (2006). Temperature-dependent protection against Ichthyophthirius multifiliis following immunisation of rainbow trout using live theronts. Diseases of Aquatic Organisms 72, 269-273.
Alvarez-Pellitero, P., Quiroga, M. I., Sitja-Bobadilla, A., Redondo, M. J., Palenzuela, O., Padros, F., Vazquez, S. and Nieto, J. M. (2004). Cryptosporidium scophthalmi n. sp. (Apicomplexa: Cryptosporidiidae) from cultured turbot Scophthalmus maximus. Light and electron microscope description and histopathological study. Diseases of Aquatic Organisms 62, 133-145.

Ardelli, B. F. and Woo, P. T.K. (1999). The therapeutic use of isometamidium chloride against Cryptobia salmositica in rainbow trout (Oncorhynchus mykiss). Diseases of Aquatic Organisms 37, 195-203.

Bakke, T. A., Jansen, P. A. and Hansen, L.P. (1990). Differences in host resistance of Atlantic salmon Salmo salar L. stocks to the monogenean Gyrodactylus salaris Malmberg, 1957. Fournal of Fish Biology 37, 577-587.

Bergh, O., Nilsen, F. and Samuelsen, O. B. (2001). Diseases, prophylaxis and treatment of the Atlantic halibut Hippoglossus hippoglossus: a review. Diseases of Aquatic Organisms 48, 57-74.

Bridle, A. R., Carter, C. G., Morrison, R. N. and Nowak, B. F. (2005). The effects of beta-glucan administration on macrophage respiratory burst activity in Atlantic salmon challenged with amoebic gill disease (AGD) - evidence of inherent resistance. Fournal of Fish Diseases 28, 347-356.

Buchmann, K., Dalsgaard, I. and Larsen, J.L. (1993). Diseases and injuries associated with mortality of hatchery reared Baltic cod (Gadus morhua L.) larvae. Acta Veterinaria Scandinavica 34, 385-390.

Buchmann, K., Lyholt, H. K. and Uldal, A. (1995). Parasite infections in Danish trout farms. Acta Veterinaria Scandinavica 36, 283-298.

Buchmann, K., Ogawa, K. and Lo, C.-F. (1992). Immune response of the Japanese eel (Anguilla japonica) against major antigens from the microsporean Pleistophora anguillarum) Hoshina, 1951. Fish Pathology 27, 157-161.

Buchmann, K. and Pedersen, K. (1994). A study on teleost phylogeny using specific antisera. Fournal of Fish Biology 45, 901-903.

Cecchini, S., Saroglia, M., Terova, G. and Albanesi, F. (2001). Detection of antibody response against Amyloodinium ocellatum (Brown, 1931 ) in serum of naturally infected European sea bass by an ezyme-linked immunoabsorbent assay (ELISA). Bulletin of the European Association for Fish Pathologists 21, 104-108.

Chettri, J. K., Holten-Andersen, L., Raida, M. K., Kania, P. and Buchmann, K. (2011) PAMP induced expression of immune relevant genes in head kidney leukocytes of rainbow trout (Oncorhynchus mykiss). Developmental and Comparative Immunology 35, 476-482.

Chettri, J. K., Kuhn, J. A., Jaafar, R. M., Kania, P. W., Møller, O. S. and Buchmann, K. (2012). Immune response of rainbow trout juveniles to the protozoan parasite Ichthyobodo necator: immunohistochemical and gene expression studies. In Immune Responses in Fish. DAFINET Workshop (ed. Kania, P. W. and Buchmann, K.), p. 6. Frederiksberg Bookprinter, Frederiksberg, Denmark (www.dafinet.dk).

Cobb, C.S., Levy, M. G. and Noga, E. J. (1998). Development of immunity by the tomato clownfish Amphiprion frenatus to the dinoflagellate parasite Amyloodinium ocellatum. Fournal of Aquatic Animal Health 10, 259-263.

Colorni, A. and Diamant, A. (1993). Ultrastructural features of Cryptocaryon irritans, a ciliate parasite of marine fish. European Fournal of Protistology 29, 425-434.

Dalgaard, M. B., Nielsen, C. V. and Buchmann, K. (2003). Comparative susceptibility of two races of Salmo salar (Baltic Lule river and Atlantic Conon river strains) to infection with Gyrodactylus salaris. Diseases of Aquatic Organisms 53, 173-176.

Desmukh, S., Raida, M. K., Dalsgaard, I., Chettri, J. K., Kania, P. W. and Buchmann, K. (2012). Comparative protection of two different commercial vaccines against Yersinia ruckeri serotype O1 and biotype 2 in rainbow trout (Oncorhynchus mykiss). Veterinary Immunology and Immunopathology 145, 379-385.

Dyková, I., Nowak, B.F., Peckova, H., Fiala, I., Crosbie, P. and Dvorakova, H. (2007). Phylogeny of Neoparamoeba strains isolated from marine fish and invertebrates as inferred from SSU rDNA sequences. Diseases of Aquatic Organisms 74, 57-65.

FAO (2012). The State of World Fisheries and Aquaculture. Fisheries and Aquaculture Department. www.FAO.org.

Guselle, N. J., Speare, D. J. and Markham, R. J. F. (2010). Efficacy of intraperitoneally and orally administered ProVale, a yeast beta- $(1,3) /(1,6)$ D-glucan product, in inhibiting xenoma formation by the microsporidian Loma salmonae on rainbow trout gills. North American Fournal of Aquaculture 72, 65-72.

Heuch, P. A., Jansen, P. A., Hansen, H., Sterud, E., MacKenzie, K., Haugen, P. and Hemmingsen, W. (2011). Parasite faunas of farmed cod and adjacent wild cod populations in Norway: a comparison. Aquaculture Environment Interactions 2, 1-13. 
Holten-Andersen, L., Dalsgaard, I. and Buchmann, K. (2012). Baltic salmon, Salmo salar, from Swedish River Lule Älv is more resistant to furunculosis compared to rainbow trout. PLoS ONE 7: e29571, 1-5.

Hung, H. W., Lo, C. F., Tseng, C. C. and Kou, G. H. (1996). Humora immune response of Japanese eel, Anguilla japónica Temminck \& Schlegel, to Pleistophora anguillarum Hoshina, 1951 (Microspora). Fournal of Fish Diseases 19, 243-250

Iglesias, R., Paramá, A., Alvarez, M. F., Leiro, J., Fernandez, J. and Sanmartín, M.L. (2002). Antiprotozoals effective in vitro against the scuticociliate fish pathogen Philasterides dicentrarchi. Diseases of Aquatic Organisms 49, 191-197.

Isaksen, T. E., Karlsbakk, E., Repstad, O. and Nylund, A. (2012). Molecular tools for the detection and identification of Ichthyobodo spp. (Kinetoplastida), important fish parasites. Parasitology International 61 675-683.

Jaafar, R. M. and Buchmann, K. (2011). Toltrazuril (Baycox vet.) in feed can reduce Ichthyophthirius multifiliis invasion of rainbow trout (Salmonidae). Acta Ichthyologica et Piscatoria 41, 63-66.

Jaafar, R. M., Skov, J., Kania, P. W. and Buchmann, K. (2011). Dosedependent effects of dietary immunostimulants on rainbow trout immune parameters and susceptibility to the parasite Ichthyophthirius multifiliis. Fournal of Aquaculture Research and Development S3, S3-001.

Jørgensen, A. and Sterud, E. (2006). The marine pathogenic genotype of Spironucleus barkhanus from farmed salmonids redescribed as Spironucleus salmonicida n. sp. Eukaryote Microbiology 53, 531-541.

Jørgensen, L. v. G. and Buchmann, K. (2011). Cysteine proteases as potential antigens in antiparasitic DNA vaccines. Vaccine 29, 5575-5583.

Jørgensen, L. v. G., Heinecke, R. D., Skjoedt, K., Rasmussen, K. J. and Buchmann, K. (2011). Experimental evidence for direct in situ binding of IgM and IgT to early trophonts of Ichthyophthirius multifilii (Fouquet) in the gills of rainbow trout, Oncorhynchus mykiss (Walbaum). Fournal of Fish Diseases 34, 749-755.

Jørgensen, T. R., Larsen, T. B., Jørgensen, L. v. G., Bresciani, J. and Buchmann, K. (2007). Isolation and characterisation of non-pathogenic form of Gyrodactylus salaris from rainbow trout. Diseases of Aquatic Organisms 73, 235-244.

Kent, M. L., Fournie, J.W., Dawe, S.C., Bagshaw, J.W. and Whitaker, D. J. (1992). Systemic hexamitid (Protozoa: diplomonadida) infection in seawater pen-reared Chinook salmon Oncorhynchus tshawytscha. Diseases of Aquatic Organisms 14, 81-89.

Lee, E. H. and Kim, K.H. (2009). CpG-ODN increases resistance of olive flounder (Paralichthys olivaceus) against Philasterides dicentrarch (Ciliophora: Scuticociliatea) infection. Fish and Shellfish Immunology 26 29-32.

León-Rodríguez, L., Luzardo-Alvares, A., Blanco-Méndez, J., Lamas, J. and Leiro, J. (2012). A vaccine based on biodegradable microspheres induces protective immunity against scuticociliates without producing side effects in turbot. Fish and Shellfish Immunology 33, 21-27.

Levy, M. G., Poore, M. F., Colorni, A., Noga, E. J. and Litaker, R. W (2007). A PCR assay for detection of Amyloodinium ocellatum. Diseases of Aquatic Organisms 73, 219-226.

Lindenstrøm, T., Sigh, J., Dalgaard, M. B. and Buchmann, K. (2006) Skin expression of IL-1 beta in East Atlantic salmon, Salmo salar L., highly susceptible to Gyrodactylus salaris infection is enhanced compared to a low susceptibility Baltic stock. Fournal of Fish Diseases 29, 123-128.

Lom, J. and Dyková, I. (1992). Protozoan Parasites of Fishes. Development in Aquaculture and Fisheries Science 26. Elsevier, Amsterdam. 315 pp.

Lorenzen, E., Einer-Jensen, K., Martinussen, T., LaPatra, S. and Lorenzen, N. (2000). DNA vaccination of rainbow trout against viral haemorrhagic septicemia virus: a dose-response and time course study Fournal of Aquatic Animal Health 12, 167-180.

Lovy, J., Wright, G. M. and Speare, D. J. (2006). Morphological presentation of a dendritic-like cell within the gills of Chinook salmon infected with Loma salmonae. Developmental and Comparative Immunology 30, 259-263.

Madsen, H.C.K., Buchmann, K. and Mellergaard, S. (2000a) Treatment of trichodiniasis in eel Anguilla anguilla in recirculated systems in Denmark: alternatives to formaldehyde. Aquaculture 186, 221-231. Madsen, H. C. K., Buchmann, K. and Mellergaard, S. (2000b) Association between trichodiniasis in eel (Anguilla anguilla) and water quality in recirculation systems. Aquaculture 187, 275-281.

Millet, C. O. M., Lloyd, D., Williams, C., Williams, D., Evans, G., Saunders, R. A. and Cable, J. (2011). Effect of garlic and allium derived products on the growth and metabolism of Spironucleus vortens. Experimental Parasitology 127, 490-499.

Misumi, I., Lewis, T. D., Takemura, A. and Leong, J. A. C. (2011). Elicited cross-protection and specific antibodies in Mozambique tilapia
(Oreochromis mossambicus) against two different immobilization serotypes of Cryptocaryon irritans isolated in Hawai. Fish and Shellfish Immunology 30, $1152-1158$

Mori, K. I., Yamamoto, K., Teruya, K., Shiozawa, S., Yoseda, K., Sugaya, T., Shirakashi, S., Itoh, N. and Ogawa, K. (2007). Endoparasitic dinoflagellate of the genus Ichthyodinium infecting fertilized eggs and hatched larvae observed in the seed production of leopard coral grouper Plectropomus leopardus. Fish Pathology 42, 49-57.

Nelson, J.S. (2006). Fishes of the World, 4th Edn. John Wiley \& Sons, Hoboken, NJ, USA.

Noga, E. J. (1987). Propagation in cell culture of the dinoflagellate Amyloodinium, an ectoparasite of marine fishes. Science 236, 1302-1304. Noga, E. J. (2012). Amyloodinium ocellatum. In Fish Parasites - Pathobiology and Protection (ed. Woo, P. T. K. and Buchmann, K.), pp. 19-29. CAB International, Wallingford, UK.

Nowak, B. F. (2012). Neoparamoeba perurans. In Fish Parasites Pathobiology and Protection (ed. Woo, P. T. K. and Buchmann, K.), pp. 118. CAB International, Wallingford, UK

Olsen, M. M., Heinecke, R. D., Skjødt, K., Rasmussen, K. J., Kania, P. and Buchmann, K. (2011). Cellular and humoral factors involved in the response of rainbow trout gills to Ichthyophthirius multifiliis infections: molecular and immunohistochemical studies. Fish and Shellfish Immunology 30, 859-869.

Paperna, I. (1981). Amyloodinium ocellatum (Browne, 1931) (Dinoflagellida) infestations in cultured marine fish at Eilat, Red Sea: epizootiology and pathology. Fournal of Fish Diseases 3, 363-272.

Pedersen, B. H., Buchmann, K. and Køie, M. (1993). Baltic larval cod Gadus morhua are infested with a protistan endoparasite in the yolk sac. Diseases of Aquatic Organisms 16, 29-33.

Pereira, J.C., Abrantes, I., Martins, I., Barata, I., Frias, P. and Pereira, I. (2011). Ecological and morphological features of Amyloodinium ocellatum occurrences in cultivated gilthead seabream Sparus aurata L.: case study. Aquaculture 310, 289-297.

Picón-Camacho, S.M., Ruiz de Ybáñez, M. R., Holzer, A.S. Arizcun, M. A. and Muñoz, P. (2011). In vitro treatments for the theron stage of the ciliate protozoan Cryptocaryon irritans. Diseases of Aquatic Organisms 94, 167-172.

Poppe, T. T., Mo, T. A. and Iversen, L. (1992). Disseminated hexamitosis in sea-caged Atlantic salmon, Salmo salar. Diseases of Aquatic Organisms 14, 91-97.

Rodgers, C. J. and Furones, M. D. (1998). Disease problems in cultured marine fish in the Mediterranean. Fish Pathology 33, 157-164.

Rodríguez-Tovar, L.E., Becker, J. A., Markham, R. J. and Speare, D. J. (2006). Induction time for resistance to microsporidial gill disease caused by Loma salmonae following vaccination of rainbow trout (Oncorhynchus mykiss) with a spore based vaccine. Fish and Shellfish Immunology 21, 170-175.

Rozas, M., Bohle, H., Grothusen, H. and Bustos, P. (2012) Epidemiology of amoebic gill disease (AGD) in Chilean salmon industry between 2007 and 2010. Bulletin of the European Association of Fish Pathologists 32, 181-188.

Rückert, S., Palm, H. W. and Klimpel, S. (2008). Parasite fauna of seabass (Lates calcarifer) under mariculture conditions in Lampung Bay, Indonesia. Fournal of Applied Ichthyology 24, 321-327.

Sánchez, J. G., Speare, D. J., Markham, R. J.F. and Jones, S. R. M. (2001). Experimental vaccination of rainbow trout against Loma salmonae using a live low-virulence variant of L. salmonae. Fournal of Fish Biology 59, 427-441.

Saraiva, A., Ramos, M.F., Barandela, T., Sousa, J. A. and Rodrigues, P. N. (2009). Cryptosporidium sp. (Apicomplexa) from cultured turbot Psetta máxima. Bulletin of the European Association of Fish Pathologists 29, 34-36.

Saraiva, A., Jeronimo, D. and Cruz, C. (2011). Amyloodinium ocellatum (Chromalveolata, Dinoflagellata) in farmed turbot. Aquaculture 320, 34-36.

Schmahl, G., Taraschewski, H. and Mehlhorn, H. (1989). Chemotherapy of fish parasites. Parasitology Research 75, 503-511.

Segner, H., Sundh, H., Buchmann, K., Douxfils, J., Sundell, K. S., Mathieu, C., Ruane, N., Jutfelt, F., Toften, H. and Vaughan, L. (2012) Health of farmed fish: its relation to fish welfare and its utility as welfare indicator. Fish Physiology and Biochemistry 38, 85-105.

Skov, J., Kania, P. W., Holten-Andersen, L., Fouz, B. and Buchmann, K. (2012). Immunomodulatory effects of dietary beta-1,3glucan from Euglena gracilis in rainbow trout (Oncorhynchus mykiss) immersion vaccinated against Yersinia ruckeri. Fish and Shellfish Immunology 33, 111-120.

Skovgaard, A., Meyer, S., Overton, J. L., Støttrup, J. and Buchmann, K. (2010). Ribosomal RNA gene sequences confirm that 
protistan endoparasite of larval cod Gadus morhua is Ichthyodinium sp. Diseases of Aquatic Organisms 88, 161-167.

Smith, S. A., Levy, M. G. and Noga, E. J. (1992). Development of an enzyme-linked immunosorbent assay (ELISA) for the detection of antibody to the parasitic dinoflagellate Amyloodinium ocellatum in Oreochromis aureus. Veterinary Parasitology 42, 145-155.

Smith, S. A., Levy, M. G., Noga, E. J. and Gerig, T.M. (1993). Effect of serum from tilapia Oreochromis aureus, immunized with dinospores of Amyloodinium ocellatum, on the motility, infectivity and growth of the parasite in cell culture. Diseases of Aquatic Organisms 15, 73-80.

Soares, F., Quental-Ferreira, H., Moreira, M., Cunha, E., Ribeiro, L. and Pousao-Ferreira, P. (2012). First report of Amyloodinium ocellatum in farmed meagre (Argyrosomus regius). Bulletin of the European Association for Fish Pathologists 32, 30-33.

Song, J.Y., Kitamura, S. I., Oh, M. J., Kang, H. S., Lee, J. H., Tanaka, S-J. and Jung, S.-J. (2009). Pathogenicity of Miamiensis avidus (syn. Philasterides dicentrarchi), Pseudocohnilembus persalinus, Pseudocohnilembus hargisi and Uronema marinum (Ciliophora, Scuticociliatida). Diseases of Aquatic Organisms 83, 133-143.

Speare, D. J. and Lovy, J. L. (2012). Loma salmonae and related species. In Fish Parasites - Pathobiology and Protection (ed. Woo, P. T. K. and Buchmann, K.), pp. 109-130. CAB International, Wallingford, UK.

Sterud, E., Mo, T. A. and Poppe, T. T. (1998). Systemic spironucleosis in sea-farmed Atlantic salmon Salmo salar, caused by Spironucleus barkhanus transmitted from feral Arctic char Salvelinus alpinus. Diseases of Aquatic Organisms 33, 63-66.

Tan, C. W., Jesudhasan, R. R. R. and Woo, P. T. K. (2008). Towards a metalloprotease-DNA vaccine against piscine cryptobiosis caused by Cryptobia salmositica. Parasitology Research 102, 265-275.
Uldal, A. and Buchmann, K. (1996). Parasite host relations: Hexamita salmonis in rainbow trout Oncorhynchus mykiss. Diseases of Aquatic Organisms 25, 229-231.

Urawa, S. (1992). Epidermal responses of chum salmon (Oncorhynchus keta) fry to the ectoparasitic flagellate Ichthyobodo necator. Canadian Fournal of Zoology 70, 1567-1575.

Urawa, S., Ueki, N. and Karlsbakk, E. (1998). A review of Ichthyobodo infection in marine fishes. Fish Pathology 33, 311-320.

Woo, P. T. K. (1979). Trypanoplasma salmositica: experimental infections in rainbow trout, Salmo gairdneri. Experimental Parasitology 47, 36-48.

Woo, P. T. K. (2012). Cryptobia (Trypanoplasma) salmositica. In Fish Parasites - Pathobiology and Protection (ed. Woo, P. T. K. and Buchmann, K.), pp. 30-54. CAB International, Wallingford, UK.

Woo, P. T. K. and Li, S. (1990). In vitro attenuation of Cryptobia salmositica and its use as a live vaccine against cryptobiosis in Oncorhynchus mykiss. Fournal of Parasitology 78, 752-755.

Xueqin, J., Kania, P. W. and Buchmann, K. (2012). Comparative effects of four feed types on white spot disease susceptibility and skin immune parameters in rainbow trout, Oncorhynchus mykiss (Walbaum). Fournal of Fish Diseases 35, 127-135.

Yambot, A. V., Song, Y. L. and Sung, H. H. (2003). Characterization of Cryptocaryon irritans, a parasite isolated from marine fishes in Taiwan. Diseases of Aquatic Organisms 54, 147-156.

Young, N.D., Crosbie, P.B.B., Adams, M. B., Nowak, B.F. and Morrison, R. N. (2007). Neoparamoeba perurans n.sp., an agent of amoebic gill disease of Atlantic salmon (Salmo salar). International fournal for Parasitology 37, 1469-1481.

Young, N. D., Dyková, I., Nowak, B. F. and Morrison, R. N. (2008). Development of a diagnostic PCR to detect Neoparamoeba perurans, agent of amoebic gill disease (AGD). Fournal of Fish Diseases 31, 285-295. 